\title{
Fenolik Total Fraksi Etil Asetat Daun Pelawan (Tristaniopsis merguensis Griff.)
}

\author{
Robby Gus Mahardika ${ }^{1,{ }^{*}}$, Occa Roanisca ${ }^{1}$, dan Fajar Indah Puspita Sari ${ }^{1}$ \\ ${ }^{1} J u r u s a n$ Kimia, Fakultas Teknik, Universitas Bangka Belitung, Bangka Belitung \\ *email korespondensi: robbygusmahardika@gmail.com
}

Received : 26 November 2019; Revised : 5 Desember 2019; Accepted : 25 Maret 2020; Published : 5 April 2020

\section{ABSTRAK}

Senyawa fenolik merupakan senyawa yang telah digunakan secara luas khususnya dibidang kesehatan dan pangan. Banyak aktivitas biologis yang dihasilkan dari senyawa fenolik, diantaranya antioksidan, antiinflamasi, antikanker dan antimutagenik. Akan tetapi, penggunaan senyawa fenolik sintetik untuk antioksidan seperti BHT (butylated hydroxytoluen), TBHQ (tertbutylhydroxy quinone), dan BHA (butylated hydroxyanisole) dilaporkan memiliki efek samping dengan ditemukannya penyakit degeneratif seperti kanker, kardiovaskuler, dan lain-lain. Sumber utama senyawa fenolik selain dari sintetik yaitu dari bahan alam yang dapat berasal dari tumbuh-tumbuhan. Salah satu spesies tumbuhan yang dipercaya oleh masyarakat Bangka sebagai antioksidan dan antidabetes adalah Tristaniopsis merguensis Griff. Manfaat tumbuhan ini sebagai obat tradisional sangat banyak, tetapi informasi metabolit sekunder dari Tristaniopsis merguensis masih terbatas khususnya di Indonesia. Oleh sebab itu, perlu adanya identifikasi senyawa aktif dari spesies Tristaniopsis merguensis Bangka. Penelitian ini bertujuan mengkaji fenolik total dari tumbuhan Tristaniopsis merguensis Griff. Ekstraksi pada penelitian ini menggunakan metode maserasi. Ekstrak aseton yang didapat selanjutnya difraksinasi dengan metode partisi cair-cair dengan pelarut etil asetat menggunakan corong pisah. Penentuan kadar fenolik total dilakukan berdasarkan metode Folin-Ciocalteau dengan standar asam galat. Hasil penelitian ini menunjukkan bahwa fraksi etil asetat dari ekstrak aseton daun Tristaniopsis merguensis mengandung senyawa fenolik total $86,724 \pm 1,83 \mathrm{mg} \mathrm{EAG/g}$ fraksi etil asetat kering. Berdasarkan spektrum FT-IR, fraksi etil asetat Tristaniopsis merguensis mengandung senyawa yang memiliki gugus $-\mathrm{OH}$ (hidroksil), $\mathrm{C}=\mathrm{O}$ dan $\mathrm{C}=\mathrm{C}$ (aromatik). Adanya gugus $-\mathrm{OH}$ (hidroksil) dan $\mathrm{C}=\mathrm{C}$ (aromatik) kemungkinan dapat berasal dari sinyal Ar-OH (fenol). Gugus Ar- $\mathrm{OH}$ ini yang menandakan adanya senyawa fenolik pada fraksi etil asetat ekstrak aseton daun Tristaniopsis merguensis.

Kata-kata kunci: fenolik; metode Folin-Ciocalteau; Tristaniopsis merguensis Griff.

\section{PENDAHULUAN}

Golongan senyawa fenolik mempunyai peran penting dalam kehidupan manusia. Senyawa ini telah digunakan secara luas, khususnya dibidang kesehatan dan pangan (Ahmad, Afrianty, Ratulangi, \& Malik, 2015). Banyak aktivitas biologis yang dihasilkan dari senyawa fenolik, diantaranya antioksidan, antiinflamasi, antikanker, dan antimutagenik. Golongan senyawa ini paling banyak digunakan sebagai antioksidan. Senyawa ini dapat bereaksi dengan radikal bebas dari reactive oxygen species (ROS) sehingga radikal yang terbentuk tidak berbahaya lagi bagi tubuh (Mahardika \& Roanisca, 2018). Akan tetapi penggunaan senyawa fenolik sintetik untuk antioksidan seperti BHT (butylated hydroxytoluen), TBHQ (tertbutylhydroxy quinone), dan BHA (butylated hydroxyanisole) dilaporkan memiliki efek samping dengan ditemukannya penyakit degeneratif seperti kanker, kardiovaskuler, dan lain-lain (Amalia \& Sariwatia, 2019). Oleh sebab itu, perlu dilakukan kajian senyawa fenolik lain untuk mengurangi efek samping tersebut, khususnya senyawa fenolik yang berasal dari bahan alam.

Sumber utama senyawa fenolik dari bahan alam yaitu berasal dari tumbuh-tumbuhan. Salah satu spesies tumbuhan yang dipercaya oleh masyarakat Bangka sebagai antioksidan dan antidabetes adalah Tristaniopsis merguensis Griff. Tumbuhan ini dikenal sebagai pohon Pelawan oleh masyarakat sekitar. Pohon Pelawan dimanfaatkan oleh masyarakat Bangka untuk mendapatkan madu Pelawan dan jamur Pelawan. Jamur Pelawan mengandung antioksidan dan asam amino esensial. Sedangkan, madu Pelawan memiliki rasa pahit bercampur rasa manis yang dipercaya sebagai obat batuk dan obat antidiabetes (Abarini, 2016). Manfaat pohon pelawan sebagai obat tradisional sangat banyak, tetapi informasi metabolit sekunder dari Tristaniopsis merguensis masih terbatas khususnya di Indonesia. Oleh sebab itu, perlu adanya identifikasi senyawa aktif dari spesies Tristaniopsis merguensis Bangka (Enggiwanto, Istiqomah, Daniati, Roanisca, \& Mahardika, 2018). 
Kajian metabolit sekunder spesies ini belum banyak dilaporkan. Spesies ini termasuk dalam genus Tristaniopsis dengan famili Myrtaceae. Kajian fitokimia yang telah dilakukan mengenai genus Tristaniopsis pada spesies Tristaniopsi obavete R.Br mengandung senyawa flavonoid, alkoloid, tanin, fenol, dan stereoid . Hasil penelitian sebelumnya yang telah dilakukan terhadap Tristaniopsis calobuxus, Tristaniopsis yateensis, dan Tristaniopsis glauca memiliki kandungan utama senyawa fenolik seperti asam ellagic dan 3,4,5-trimetoksifenil- (6'-O-galloil) -O- $\beta$-o-glukopiranosida, asam $p$-OH benzoat, asam galat, dan asam 3,4di-OH benzoat (Verotta et al., 2001). Senyawa asam ellagic mempunyai aktivitas antiplasmodial yang bagus dengan nilai $\mathrm{IC}_{50}<150 \mathrm{~g} / \mathrm{mL}$. Pada genus Tristaniopsis bagian daun rata-rata mempunyai kandungan senyawa aktif yang lebih tinggi jika dibandingkan bagian lain dari tumbuhan pada genus ini (Verotta et al., 2001). Berdasarkan penelitian yang dilakukan oleh Bellosta et al., (2003), ekstrak kulit batang dari Tristaniopsis calobuxus (Myrtaceae) juga banyak mengandung senyawa polifenol, seperti asam ellagic, (+)galokatekin, (-)-galokatekin, dan (-)-epigalokatekin. Tipe senyawa asam ellagic yang banyak ditemukan merupakan asam ellagic yang terglikosidasi seperti silosa, arabinosa, dan ramnosa (Bellosta et al., 2003). Banyaknya senyawa fenolik pada genus tersebut maka perlu dilakukan kajian mengenai total fenolik dari spesies Tristaniopsis merguensis Griff.

Berdasarkan penelitian sebelumnya, fraksi etil asetat batang jarak (Ricinus communis L.) memiliki aktivitas antioksidan yang lebih tinggi dibandingkan fraksi $n$-heksana, dan fraksi metanol. Fraksi etil asetat batang jarak memiliki nilai $I \mathrm{I}_{50}$ sebesar $24,38 \mathrm{ppm}$ sedangkan $\mathrm{IC}_{50}$ fraksi $\mathrm{n}$-heksana dan metanol masingmasing yaitu 289,05 dan 33,38 ppm (Agustina, Nurhadimah, \& Handayani, 2017). Kandungan fenolik total fraksi etil asetat rambut jagung (Zea Mays L.) memiliki nilai 140,25 $\pm 1,43 \mathrm{mg}$ EAG/g. Kandungan ini lebih tinggi jika dibandingkan fraksi n-heksan, fraksi air, dan ekstrak metanol pada sampel yang sama (rambut jagung (Zea Mays L.) (Samin, Bialangi, \& Salimi, 2013). Begitu juga kandungan fenolik total daun jambu mete (Anacardium occidentale L.), fraksi etil asetat juga memiliki kandungan fenolik yang lebih tinggi dibandingkan ekstrak etanol, fraksi kloroform, fraksi n-heksana, dan fraksi polar (air). Nilai fenolik total pada fraksi etil aseta jambu mete adalah sebesar 422,75 \pm 19,787 mg EAG/g (Trisharyanti, Melannisa, \& Ratri, 2011). Struktur senyawa fenolik yang bersifat semi polar membuat pelarut etil asetat banyak digunakan untuk mengambil senyawa fenolik dari tumbuhan. Oleh sebab itu penelitian ini akan mengkaji kandungan fenolik pada fraksi etil asetat daun Tristaniopsisi merguensis.

\section{EKSPERIMEN}

\section{Alat dan Bahan}

Alat yang digunakan pada penelitian ini diantaranya: pipet tetes, tabung reaksi, botol vial, labu ukur, pipet volume, corong pisah, alat maserasi, gelas ukur, vortex mixer Thermolyne $3000 \mathrm{rpm}$, dan rotary evaporator vacuum IKA RV. Fenolik total dianalisis menggunakan spektrofotometer UV-Vis Shimadzu sedangkan identifikasi gugus fungsi diukur menggunakan FT-IR Thermolyne metode pellet KBr. Sampel penelitian yang digunakan yaitu daun Tristaniopsis merguensis Griff. yang diperoleh dari desa Kimak, Kabupaten Bangka. Bahan lain yang digunakan diantaranya: aseton teknis, $\mathrm{n}$-heksana teknis, etil asetat teknis, aquades, alumunium foil, kertas saring, dan beberapa bahan dengan grade pro-analysis dari Merck seperti metanol, reagen Folin-Ciocalteau, asam galat, serta natrium karbonat $\left(\mathrm{Na}_{2} \mathrm{CO}_{3}\right) 7,5 \%$,

\section{Prosedur Kerja}

\section{Preparasi sampel}

Sampel daun segar Tristaniopsis merguensis dikeringkan lalu dipotong dan dihaluskan. Serbuk kering diayak sehingga didapatkan ukuran serbuk 100 mesh. Serbuk ini selanjutnya diekstraksi menggunakan metode maserasi.

\section{Ekstraksi}

Seberat $100 \mathrm{~g}$ serbuk kering daun Tristaniopsis merguensis yang ukurannya sudah sesuai selanjutnya direndam dengan pelarut aseton sebanyak $1000 \mathrm{~mL}$ selama $3 \times 24$ jam. Hasil dari proses ini diuapkan menggunakan rotary evaporator vacuum hingga didapatkan ekstrak kering. 


\section{Proses fraksinasi}

Metode fraksinasi yang dilakukan menggunakan metode fraksinasi cair-cair. Langkah yang dilakukan yaitu seberat $20 \mathrm{~g}$ ekstrak kering dalam aseton dilarutkan dalam metanol $100 \mathrm{~mL}$ dan dimasukkan ke dalam corong pisah untuk diekstraksi menggunakan pelarut $n$-heksana terlebih dahulu sebanyak $100 \mathrm{~mL}$. Ekstraksi dengan pelarut ini dilakukan sebanyak 3 kali pengulangan terhadap ekstrak yang sama. Kedua fraksi tersebut selanjutnya dipisahkan. Fraksi metanol ditambahkan air sebanyak $10 \%$ dari volume yang didapat (v/v). Larutan yang sudah ditambahkan air ini kemudian diekstraksi dengan etil asetat sebanyak 3 kali pengulangan sehingga didapatkan fraksi etil asetat. Fraksi etil asetat selanjutnya diuapkan menggunakan rotary evaporator vacuum untuk mendapatkan fraksi etil asetat kental. Fraksi etil asetat ini selanjutnya dilakukan penentuan kadar fenolik total dan karakterisasi fraksi berdasarkan analisis gugus fungsi terhadap fraksi etil asetat.

\section{Penentuan Kandungan Fenolik Fotal}

Uji kandungan senyawa fenolik dilakukan secara kuantitatif dengan metode uji Folin-Ciocalteau (Safdar et al., 2017). Seberat $5 \mathrm{mg}$ sampel fraksi etil asetat dilarutkan dalam $25 \mathrm{~mL}$ metanol. Sebanyak 0,5 $\mathrm{mL}$ larutan ini dimasukkan dalam tabung reaksi. Selanjutnya ditambahkan reagen Folin-Ciocalteau $10 \%$ sebanyak 2,5 mL. Campuran ini kemudian dikocok dan didiamkan sekitar 2 menit. Setelah itu, dalam tabung reaksi yang sama ditambahkan $2,5 \mathrm{~mL} \mathrm{Na}{ }_{2} \mathrm{CO}_{3} 7,5 \%$. Kemudian diaduk menggunakan vortexer salama 30 detik. Campuran ini selanjutnya diinkubasi pada suhu $27^{\circ} \mathrm{C}$ selama 30 menit. Larutan blanko pada uji ini digunakan metanol $(0,5 \mathrm{~mL})$ yang dicampur dengan reagen Folin-Ciocalteau $10 \%(2,5 \mathrm{~mL})$ dan $\mathrm{Na}_{2} \mathrm{CO}_{3} 7,5 \%$ $(2,5 \mathrm{~mL})$. Pengukuran kandungan fenolik total dianalisis menggunakan metode spektroskopi UV-Vis. Pengukuran dilakukan pada absorbansi dengan panjang gelombang $(\lambda) 765 \mathrm{~nm}$. Nilai ini fenolik total ditentukan berdasarkan pengukuran panjang gelombang yang sama pada larutan standard asam galat. Asam galat dibuat dalam konsentrasi 25, 50, 75, 100, 150, dan 200 ppm. Fenolik total fraksi etil asetat dihitung berdasarkan kurva kalibrasi standar asam galat dan dinyatakan dalam mg ekuivalen asam galat $(\mathrm{EAG}) / \mathrm{g}$.

\section{Analisis Gugus Fungsi Fraksi Etil Asetat}

Karakterisasi gugus fungsi fraksi etil asetat dilakukan dengan menggunakan spektrofotometer FT-IR. Analisis gugus fungsi didasarkan pada serapan yang dihasilkan pada bilangan gelombang tertentu. Serapan yang dihasilkan dibandingkan dengan referensi yang ada.

\section{HASIL DAN DISKUSI}

Hasil ekstraksi dengan pelarut aseton terhadap daun Tristaniopsis merguensis didapatkan ekstrak aseton kental. Pelarut aseton dipilih karena sifatnya yang sedikit polar dan tidak bercampur dengan air sehingga harapannya dapat memisahkan antara senyawa fenolik dengan senyawa yang lebih polar seperti karbohidrat (Dewi, Estiasih, \& Murtini, 2007). Ekstrak tersebut dipartisi dengan pelarut $n$-heksana terlebih dahulu dan dilanjutkan dengan pelarut etil asetat menggunakan corong pisah. Tujuan penggunaan nheksana adalah untuk menghilangkan senyawa-senyawa non polar yang terkandung dalam ekstrak aseton daun Tristaniopsis merguensis seperti klorofil, steroid, maupun terpenoid. Hal ini karena pelarut $\mathrm{n}$-heksana yang bersifat non polar. Penggunaan pelarut etil asetat bertujuan untuk dapat menarik atau melarutkan senyawa-senyawa yang bersifat semi polar seperti golongan polifenol maupun flavonoid. Fraksi ini yang selanjutkan akan dianalisis kandungan fenolik total secara kuantitatif.

Pengukuran kandungan fenolik total dilakukan menggunakan metode Folin-Ciocalteau dengan standard asam galat. Asam galat sendiri memiliki struktur 3,4,5-trihidroksibenzoat yang merupakan golongan asam fenolik. Kandungan total fenolik didasarkan pada terbentuknya senyawa kompleks fosfomolibdat-fosfotungsat berwarna biru sehingga dapat dilakukan pengukuran absorbansi pada panjang gelombang $765 \mathrm{~nm}$ (Kusbandari \& Prasetyo, 2018). Kompleks ini terbentuk karena reduksi senyawa fenolik dalam suasana basa. Standar asam galat yang digunakan yaitu 25, 50, 75, 100, 150, dan 200 ppm. Absorbansi hasil pengukuran ini diplot terhadap konsentrasi sehingga didapatkan persamaan linier (Gambar 1). 


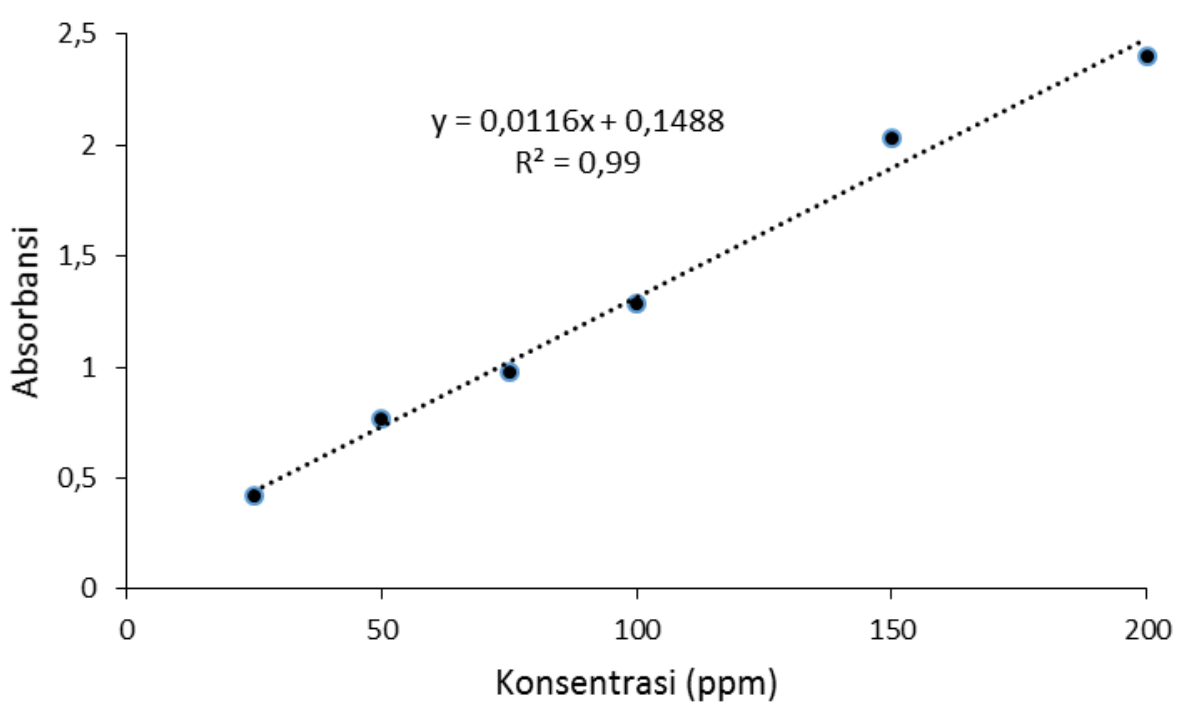

Gambar 1. Kurva kalibrasi absorbansi asam galat terhadap konsentrasi.

Hasil analisis fenolik total disajikan pada Tabel 1. Sampel fraksi etil asetat dari ekstrak aseton daun Tristaniopsis merguensis juga diukur pada panjang gelombang tersebut sehingga didapatkan absorbansi rata-rata sebesar 0,350 . Nilai absorbansi tersebut dimasukkan dalam persamaan garis dari kurva kalibrasi asam galat sehingga didapatkan konsentrasi $17,345 \pm 0,36 \mathrm{ppm}$. Jika sampel fraksi yang digunakan seberat $5 \mathrm{mg}$ dalam $25 \mathrm{~mL}$, maka didapatkan kandungan fenolik totalnya sebesar $86,724 \pm 1,83 \mathrm{mg}$ EAG/g fraksi etil asetat kering. Nilai ini lebih besar dibandingkan kandungan fenolik pada ekstrak bunga Rosella (Hibiscus sabdariffa L.) 21,2 mg EAG/g ekstrak, maupun pada ekstrak Citruss reticulate L. sebesar $28 \mathrm{mg}$ EAG/g ekstrak (Riza \& Susanti, 2013). Jika dibandingkan dalam satu famili (Myrtaceae) kandungan fenolik total pada daun Tristaniopisis merguensis ini lebih tinggi dibandingkan pada ekstrak daun salam (12,96 mg EAG/g), ekstrak daun cengkeh (42,14 mg EAG/g), dan ekstrak daun jambu air (16,08 mg EAG/g) (Suryanto, Momuat, Frenly, \& Patty, 2010).

Tabel 1. Hasil analisis fenolik total fraksi etil asetat daun Tristaniopsis merguensis

\begin{tabular}{cccccc}
\hline Sampel & Replikasi & Absorbansi & Konsentrasi (ppm) & $\begin{array}{c}\text { Fenolik Total } \\
\text { (mg EAG/g) }\end{array}$ & $\begin{array}{c}\text { Rata-rata Fenolik } \\
\text { Total (mg EAG/g) }\end{array}$ \\
\hline Fraksi Etil & 1 & 0,347 & 17,08621 & 85,43103 & $86,724 \pm 1,83$ \\
Asetat & 2 & 0,353 & 17,60345 & 88,01720 & \\
\hline
\end{tabular}

\section{Karakterisasi Fraksi Etil Asetat Berdasarkan Pengukuran FT-IR}

Fraksi etil asetat Tristaniopsis merguensis yang didapat lalu dilakukan analisis gugus fungsi dengan menggunakan spektrofotometer FT-IR. Spektrum FT-IR fraksi etil asetat daun Tristaniopsis merguensis disajikan pada Gambar 2 dan Tabel 2. Serapan melebar $3400-3100 \mathrm{~cm}^{-1}$ menunjukkan adanya vibrasi gugus $-\mathrm{OH}$ streching (hidroksil), pita yang melebar diakibatkan adanya interaksi ikatan hidrogen intermolekul. Pita gugus hidroksil dapat berasal dari gugus fenol $(\mathrm{Ar}-\mathrm{OH})$ yang diperkuat terdapatnya serapan pada bilangan gelombang $750,88 \mathrm{~cm}^{-1}$. Pita gugus $\mathrm{OH}$ yang melebar ini kemungkinan juga bertumpang tindih dengan serapan C-H aromatik stretching yang biasanya berada pada 3159-3050 $\mathrm{cm}^{-1}$ (Maobe et al., 2013). Hal ini menandakan adanya gugus aromatik pada ekstrak. Keberadaan aromatik juga didukung dengan adanya vibrasi $\mathrm{C}=\mathrm{C}$ stretching pada $1610,31 \mathrm{~cm}^{-1}$. Analisis tersebut menunjukkan bahwa ekstrak Tristaniopsis merguensis terdapat senyawa aromatik yang diduga mengandung senyawa fenolik atau polifenol. 


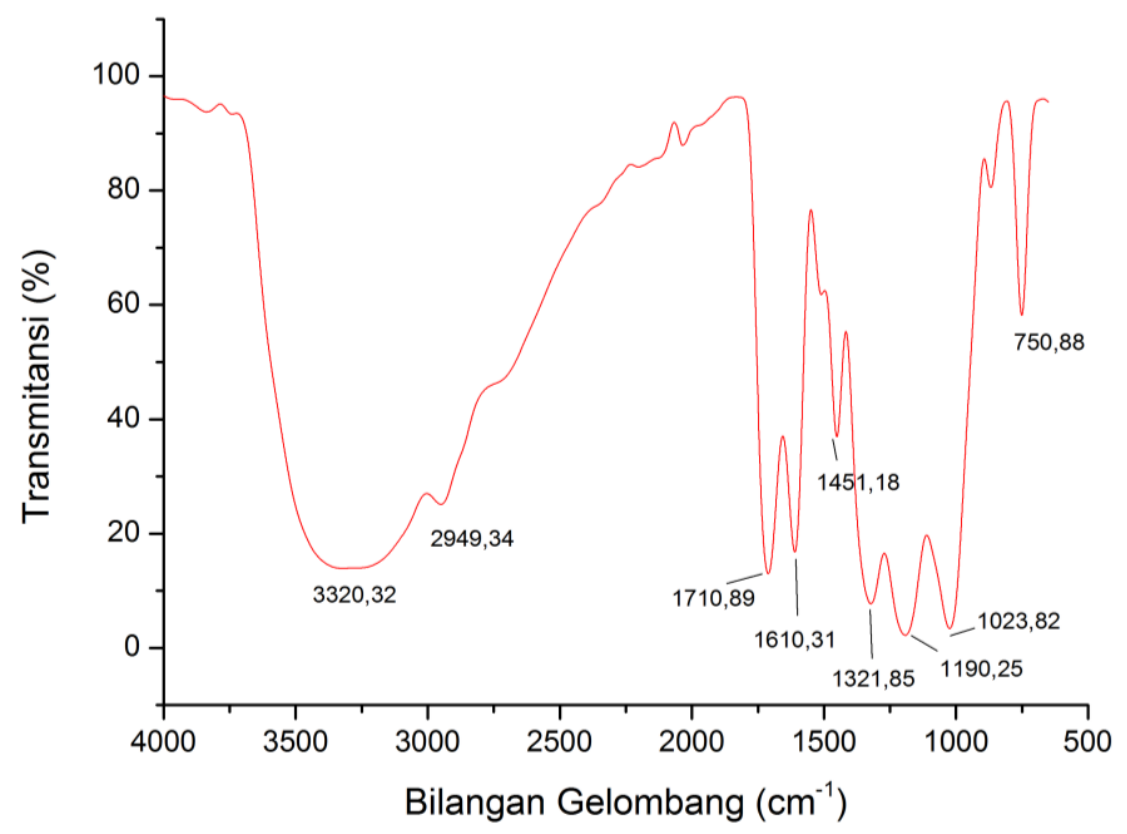

Gambar 2. Spektrum FT-IR fraksi etil asetat daun Tristaniopsis merguensis.

Pita dengan bilangan gelombang $2949,34 \mathrm{~cm}^{-1}$ menunjukkan adanya gugus $\mathrm{CH}_{3}$ (metil) dan vibrasi asimetris $\mathrm{CH}_{2}$ (metilen). Adanya gugus tersebut juga didukung dengan munculnya pita pada bilangan gelombang 1451,18 sampai 1321,85 cm $\mathrm{cm}^{-1}$. Hal ini menandakan bahwa ekstrak Tristaniopsis merguensis mengandung gugus metil, metilen, dan metin (Roanisca, Mahardika, \& Setiawan, 2019).

Tabel 2. Mode vibrasi gugus fungsi dari sepktrum FT-IR fraksi etil asetat Triastaniopsis merguensis

\begin{tabular}{cc}
\hline Bilangan Gelombang $\left(\mathrm{cm}^{-1}\right)$ & Mode Vibrasi \\
\hline 3320,32 & $-\mathrm{OH}$ streching \\
2949,34 & $\mathrm{CH}_{3}$ streching, asymmetric $\mathrm{CH}_{2}$ streching \\
1710,89 & $\mathrm{C}=\mathrm{O}$ streching \\
1610,31 & $\mathrm{C}=\mathrm{C}$ aromatic stretching \\
1451,18 & $\mathrm{CH}_{2}$ bending \\
1321,85 & $\mathrm{C}-\mathrm{H}$ bending \\
1023,82 & $\mathrm{C}-\mathrm{O}$ alkohol stretching \\
750,88 & $\mathrm{C}-\mathrm{H}$ aromatic bend \\
\hline
\end{tabular}

Serapan kuat lain ada pada bilangan gelombang $1710,89 \mathrm{~cm}^{-1}$, pita tersebut menandakan adanya vibrasi dari gugus $\mathrm{C}=\mathrm{O}$ (karbonil). Jika dilihat dari serapan yang lain maka gugus karbonil ini diduga mengandung gugus keton atau asam karboksilat. Hal ini karena tidak terdapatnya pita pada bilangan gelombang $1280-1150 \mathrm{~cm}^{-1}$ yang menandakan adanya gugus C-O-C ester, atau tidak terdapatnya serapan pada kisaran 2800 yang menandakan adanya C-H aldehid.

Berdasarkan analisis data spektrum FT-IR (Gambar 2), fraksi etil asetat Tristaniopsis merguensis mengandung senyawa yang memiliki gugus $-\mathrm{OH}$ (hidroksil), $\mathrm{C}=\mathrm{O}$ dan $\mathrm{C}=\mathrm{C}$ (aromatik). Adanya gugus $-\mathrm{OH}$ (hidroksil) dan $\mathrm{C}=\mathrm{C}$ (aromatik) kemungkinan berasal dari sinyal $\mathrm{Ar}-\mathrm{OH}$ (fenol). Sehingga dalam fraksi etil asetat daun Tristaniopsis merguensis diduga mengandung senyawa dengan struktur fenolik. Hal ini diperkuat dengan adanya kandungan senyawa fenolik dengan kadar fenolik total sebesar $86,724 \pm 1,83 \mathrm{mg}$ EAG/g.

\section{KESIMPULAN}

Fraksi etil asetat dari ekstrak aseton daun Tristaniopsis merguensis Griff. memiliki kandungan fenolik total $86,724 \pm 1,83 \mathrm{mg} \mathrm{GAE} / \mathrm{g}$ fraksi etil asetat kering. Jika melihat spektrum FT-IR, fraksi etil asetat Tristaniopsis merguensis mengandung senyawa yang memiliki gugus $-\mathrm{OH}$ (hidroksil), $\mathrm{C}=\mathrm{O}$ dan $\mathrm{C}=\mathrm{C}$ (aromatik). Adanya gugus $-\mathrm{OH}$ (hidroksil) dan $\mathrm{C}=\mathrm{C}$ (aromatik) kemungkinan berasal dari sinyal $\mathrm{Ar}-\mathrm{OH}$ (fenol). Sehingga dalam fraksi etil asetat daun Tristaniopsis merguensis diduga mengandung senyawa dengan 
struktur fenolik. Selain itu, tingginya kandungan fenolik total pada fraksi etil asetat ini perlu dilakukan uji aktivitas biologis untuk melihat khasiat dari daun Tristaniopsis merguensis.

\section{UCAPAN TERIMA KASIH}

Peneliti mengucapkan terima kasih kepada Kementrian Riset, Teknologi, dan Pendidikan Tinggi melalui hibah Penelitian Dosen Pemula (PDP) sesuai dengan Surat Keputusan Nomor 7/E/KPT/2019 dan Perjanjian/Kontrak Nomor 052/SP2H/LT/DRPM/2019 dan 187.O/UN.50.3.1/PP/2019.

\section{DAFTAR PUSTAKA}

Agustina, W., Nurhadimah, \& Handayani, D. (2017). Beberapa Fraksi Dari Kulit Batang Jarak ( Ricinus communis L .). ALOTROP Jurnal Pendidikan Dan IImu Kimia, 1(2), 117-122.

Ahmad, A. R., Afrianty, S., Ratulangi, D., \& Malik, A. (2015). Penetapan Kadar Fenolik dan Flavonoid Total Ekstrak Metanol Buah dan Daun Patikala ( Etlingera elatior ( Jack ). Pharm. Sci. Res., 2(1).

Amalia, A. W., \& Sariwatia, A. (2019). Identification of Chemical Compounds and Antioxidants of Soursop Seed Ethyl Acetate Extract (Annona mucicata Linn). Current Pharmaceutical Sciences, 3(1), 192-197.

Bellosta, S., Canavesi, M., Mitro, N., Monetti, M., Crestani, M., Verotta, L., ... Bosisio, E. (2003). Inhibition of metalloproteinase- 9 activity and gene expression by polyphenolic compounds isolated from the bark of Tristaniopsis calobuxus (Myrtaceae ). CMLS Cellular and Molecular Life Sciences, 60, 14401448. https://doi.org/10.1007/s00018-003-3119-3

Dewi, J. R., Estiasih, T., \& Murtini, S. (2007). Antioxidant Activity of Extracts Obtained by Applying Various Solvents to the Local Brown Sorghum ( Sorghum bicolor ) Bran. Jurnal Teknologi Pertanian, 8(2), 188-197.

Enggiwanto, S., Istiqomah, F., Daniati, K., Roanisca, O., \& Mahardika, R. G. (2018). Ekstraksi Daun Pelawan ( Tristaniopsis merguensis) Sebagai Antioksidan Menggunakan Microwave Assisted Extraction ( MAE ). Indonesian Journal of Pure and Applied Chemistry, 1(2), 50-55.

Kusbandari, A., \& Prasetyo, D. Y. (2018). Determination of Total Phenolic Content and Antioxidant Activity of Kawa Coffee Leaves Ethanolic Extract With Dpph Method. Media Farmasi, 15(2), 72-80.

Mahardika, R. G., \& Roanisca, O. (2018). Antioxidant Activity And Phytochemical of Extract Ethyl Acetat Pucuk Idat ( Cratoxylum glaucum ). Indo. J. Chem. Res, 5(2), 481-486.

Maobe, M. A. G., Nyarango, R. M., \& Box, P. O. (2013). Fourier Transformer Infra-Red Spectrophotometer Analysis of Urtica dioica Medicinal Herb Used for the Treatment of Diabetes, Malaria and Pneumonia in Kisii Region, Southwest Kenya. World Applied Sciences Journal, 21(8), 1128-1135. https://doi.org/10.5829/idosi.wasj.2013.21.8.2876

Riza, A., \& Susanti, H. (2013). Penetapan Kadar Fenolik Total Ekstrak Metanol Kelopak Bunga Rosella Merah (Hibiscus sabdariffaLinn) dengan Variasi Tempat Tumbuh Secara Spektrofotometri. Jurnal Ilmiah Kefarmasian, 33(3), 324-333.

Roanisca, O., Mahardika, R. G., \& Setiawan, Y. (2019). Tristaniopsis merguensis Griff . Extract as Inhibitor for Corrosion of Stainless Steel Tristaniopsis merguensis Griff . Extract as Inhibitor for Corrosion of Stainless Steel. IOP Conference Series: Earth and Environmental Science, 353012020. https://doi.org/10.1088/1755-1315/353/1/012020

Safdar, M. N., Kausar, T., Jabbar, S., Mumtaz, A., Ahad, K., \& Saddozai, A. A. (2017). Extraction and quantification of polyphenols from kinnow (Citrus reticulate $L$.) peel using ultrasound and maceration techniques. Journal of Food and Drug Analysis, 25(3), 488-500. https://doi.org/10.1016/j.jfda.2016.07.010 
Samin, A. A., Bialangi, N., \& Salimi, Y. K. (2013). Penentuan Kandungan Fenolik Total dan Aktivitas Antioksidan dari Rambut Jagung Zea Mays L yang Tumbuh di Daerah Gorontalo. Retrieved from http://repository.ung.ac.id/get/simlit_res/1/419/Penentuan-Kandungan-Fenolik-Total-danAktivitas-Antioksidan-dari-Rambut-Jagung-Zea-Mays-LYang-tumbuh-diDaerah-Gorontalo-Penullisketiga.pdf

Suryanto, E., Momuat, L., Frenly, W., \& Patty, W. (2010). Potensi Antioksidan Fenolik dari Famili Myrtaceae dan Perannya Sebagai Bahan Aktif Tabir Surya. Chem. Prog., 3(2), 74-80.

Trisharyanti, I. D. K., Melannisa, R., \& Ratri, K. (2011). Korelasi kandungan fenolik dan aktivitas antioksidan daun jambu mete. Biomedika, 3(2), 25-30.

Verotta, L., Agli, M. D., Giolito, A., Guerrini, M., Cabalion, P., \& Bosisio, E. (2001). In Vitro Antiplasmodial Activity of Extracts of Tristaniopsis Species and Identification of the Active Constituents : Ellagic Acid and 3 , 4 , 5-Trimethoxyphenyl- ( 6' - O -galloyl ) - O - - D -glucopyranoside. Journal of Natural ProductNatural Product, 64(5), 603-607. 